\title{
Developing a Lawyer's Practical Thinking at Higher Education Institution Stage of the Professionalization
}

\author{
Alexander Smirnov \\ Candidate of Psychological Sciences, Associate Professor, Associate Professor at the Chair of Pedagogics and \\ Pedagogical Psychology, P.G. Demidov Yaroslavl State University; asmirnov1970@bk.ru
}

Dmitriy Smirnov

Candidate of Legal Sciences, Associate Professor at the Chair of Labor and Financial Law P.G. Demidov Yaroslavl State University; Dima_Smirnov@bk.ru

\author{
Mariya Yurkina \\ Postgraduate Student at the Chair of Pedagogics and Pedagogical Psychology \\ P.G. Demidov Yaroslavl State University; msyurkina@mail.ru
}

\section{Doi:10.5901/mjss.2015.v6n6s5p319}

\section{Abstract}

\begin{abstract}
The paper considers the particularities of development of a lawyer's practical thinking at the higher education institution stage of professionalization. In order to achieve the set goal, the block of psychological techniques was used, in particular, several scales of $R$. Cattell's 16-factor personality questionnaire, a questionnaire for diagnosing the practical orientation of thinking, a questionnaire of creative personal capacities etc. The research was conducted with a sample of 282 students of the faculty of law of P.G. Demidov YarSU, with 143 students of the faculty of economics of P.G. Demidov YarSU as the control group (425 people in total). The study performed has shown that the development of qualities of thinking in lawyers at the higher education institution stage of professionalization is distinguished by essential heterochrony. In particular, a significant reduction of most professionally important indices has been found in year 3 of studying at the faculty of law. These indices are restored in years 4 and 5 either in full (intellect) or in part (practical orientation of thinking, development of creative personal capacities). This allows speaking about a crisis in the development of professional thinking of law students in year 3. The consequences of this crisis turn to not be overcome completely by year 5. In the paper, it is supposed that finally the consequences of the crisis found are eliminated as late as during the graduate's direct performing of the professional activity.
\end{abstract}

Keywords: professional thinking, practical thinking of a lawyer, professionalization.

\section{Introduction}

An essential prerequisite for constructing a law-governed state is formation of a mass corps of professional lawyers, i.e. people having a number of professional competencies among which there is the ability to interpret and practically apply the norms of the current law.

Legal engineering of the Russian law is already at quite a high development level. This allows a legislator to thoroughly build a perfect enough and logically uncontroversial system of regulatory prescriptions. This process, however, has a reverse side as well, namely: on the one hand, the Russian law norms are becoming more and more difficult for people who are not professional lawyers to understand, and on the other hand, the current reality imposes increasingly higher requirements to the professional lawyers themselves.

This trend entails higher requirements to both a professional lawyer and educational institutions training lawyers. As a consequence, a vital problem is to build a system of forming the lawyer's professional thinking which would be optimum for current conditions. However, for building the system, the main particularities of a lawyer's professional thinking formation have to be found out.

\subsection{Significance and relevance of the research}

The study of scientific literature has shown that the problem of professional training of lawyers is not explored sufficiently 
in the aspect of the lawyer's professional thinking formation. Therefore, the theoretical relevance of our research is conditioned by the scientific novelty. The results of the research will allow expanding the ideas about the characteristic principles of development of professional thinking in lawyers at the stage of higher education institution professionalization.

The practical significance of the research consists in the fact that its findings can serve as a basis for introducing scientifically grounded change into the process of training lawyers at the higher education institution stage of professionalization.

The applied relevance consists in developing a complex of techniques which allow monitoring the formation of professional thinking.

\section{Literature Review}

The problems of students' adaptation to new conditions, including the problems of development of their professional thinking were considered in a number of works by both Russian and foreign scientists (in particular, Smith, 2008, Taylor, 2004, Warren, 2009).

Traditionally, thinking is understood to be subdivided according to the character of tasks at solving which it is aimed into practical and theoretical (Baron, 1985, Perkins, 1989, Sternberg and Wagner, 1986). The particularities of practical thinking were studied in detail by scientists such as S.L. Rubinshtein, B.M. Teplov, Yu.K. Kornilov, M.M. Kashapov etc.

So, works of S.L. Rubinshtein pay attention to a close connection of thinking with the practical action. With regard to this, S.L. Rubinshtein uses as an original assumption the idea of unity of thinking, according to which there are no theoretical and practical thinking separately existing but there are to a certain extent artificially subdivided varieties of thinking - the theoretical and practical ones. According to S.L. Rubinshtein, "a man learns the reality by affecting it, and understands the world by changing it. Thinking is not merely accompanied by action or action - by thinking; action is the primary form of existence of thinking. The primary kind of thinking is thinking in action and by action, thinking which is performed in action and found in action" (Rubinshtein, 2006).

It is from here that the division of thinking into theoretical and practical follows. According to S.L. Rubinshtein, thinking emerged in labor activity as a practical operation aimed at solving certain tasks. It was just later when generalizing the solutions of similar tasks, going beyond a single certain case, that the theoretical thinking was born.

A milestone in studying the practical thinking was monograph of B.M. Teplov "A commander's mind". B.M. Teplov also proceeds from the idea about the principal unity of thinking and he sees the difference between theoretical and practical thinking in that of tasks which theorists and practicians set for themselves. This difference, according to Teplov, consists in theoretical and practical thinking being associated with practice in different ways: "The work of practical thinking is mainly aimed at solving particular, certain tasks - to organize work of a certain plant, to bring into life a plan of a combat etc. - while the work of theoretical thinking is mainly aimed at finding general regularities - principles of organizing the production, tactical and strategic regularities, etc." (Teplov, 1990). It is hence that such specific features of practical thinking as its close connection to certain reality, constant checking of actions performed and decisions made for correctness by practice, strict time limits, limited possibilities of using the hypotheses etc. follow. B.M. Teplov summarizes it in such a way: "...there is not a faintest ground to consider the work of practical mind simpler and more elementary than the work of theoretical mind" (Teplov, 1990).

We can agree with Yu.K. Kornilov with good reason that "...it would be a simplification to believe that theoretical thinking "obtains" knowledge about surrounding reality and practical thinking uses it when managing the activity. In point of fact, the specific nature of these kinds of thinking and their relation are much more complicated. Certainly, when transforming the world, a man relies on the knowledge of properties of the objective world that is specific for theoretical thinking. Practical thinking also performs cognition but it is different from theoretical one which is aimed at discovering laws, ways for transforming the object, particularities of its properties to resist the transformation" (Kornilov, 2000).

When considering the proportion of practical thinking and professional thinking, the psychological literature draws attention to the fact that professional thinking is in its essence a variety of practical one: both kinds of thinking are aimed at transforming. Meanwhile, professional thinking has an essential specific nature. So, M.M. Kashapov views the professional thinking as the top cognitive process of searching, discovering and resolving the problematicity, revealing the not set externally, concealed properties of the reality being learned and transformed. This author has outlined 10 essential particularities of the professional thinking as compared to practical thinking:

1. Duality of tasks solved by the professional during practical thinking (cognitive and transforming ones).

2. Subjectness of the object of a practician's work as a representative of socionomy type professions. This 
subjectness, in its turn, influences the professional activity of the practician.

3. Reflexivity of the professional thinking.

4. Independence - orientation to look for own ways for solving the constantly changing and variative situations.

5. On the one hand, generalized and global character of the goal of professional activity; on the other hand, certain and contextual character thereof.

6. Delay of made and performed decisions, which leads to hierarchy of processes and results of thinking.

7. Formedness of a professional task with the long-term and short-term prospect of development of a certain situation borne in mind.

8. Constructiveness and productivity of a professional's thinking.

9. Indirect influence of personal and professional characteristics of the practician on the professional thinking.

10. Individualization of intellectual qualities and professionalization of thinking. Responsibility, high criticism and self-criticism of the professional thinking" (Kashapov, 2007).

The particularities of a practicing lawyer's professional thinking are studied in literature quite in detail, however, even here there are a lot of debatable questions.

So, V.L. Vasiliev singles out the following particularities of the professional legal activity: first, these are extremely diverse tasks to be solved by a professional lawyer; second, this is the legal activity being completely subjected to legal regulation; third, this is a high emotional stress of a lawyer's work; fourth, this is exercise of authoritative powers characteristic for many legal professions; fifth, this is the presence of a special aspect of a lawyer's organizational activity which is manifested on the one hand in having to organize oneself and one's working time and on the other hand - in having to organize joint work with other legal activity participants; sixth, for many legal professions, overcoming of resistance on the part of individuals or micro-groups is characteristic; and seventh, a creative aspect of work is characteristic for all legal professions, which also follows from the above features of the legal activity (Vasiliev, 2009).

V.V. Romanov outlines the following particularities of the professional legal activity: legal regulation (standardization) of the professional behavior, decisions made by workers of law enforcement authorities, legal services, by other lawyers professionally participating in law enforcement activity; power, binding character of professional authorities of law enforcement agencies officers; extreme character of law enforcement activity of many lawyers, especially of ones working in judicial bodies, prosecutor's office, tax service and tax police etc.; non-standard, creative character of a lawyer's work; procedural independence, personal (for many - enhanced) responsibility of lawyers employed in law enforcement bodies, state and legal structures (Romanov, 2004).

We assume that in order to ensure efficiency in the professional legal activity the thinking of a professional lawyer has to correspond to the specific character of this activity. So, for a successful activity within the system of state governing, a high standardization of behavior and low inclination to deviant behavior are required. For a successful exercise of authoritative powers, quite a high level of development of communication and organization abilities is essential, and so on. Each of the qualities considered requires the relevant study technique.

\section{Research Methods}

We have compiled a list of qualities that are important in the practical professional activity of a lawyer. For clarity, we have drawn up the following table (Table 1) uniting the requirements of the profession, the qualities of a lawyer's thinking which correspond to the requirements, and tools for measuring the qualities.

Table 1. Consolidation table revealing the lawyer's profession requirements, qualities of a lawyer's thinking corresponding to the requirements, and tools for studying the qualities

\begin{tabular}{|l|l|l|}
\hline Particularities of the legal activity & $\begin{array}{l}\text { Qualities of a lawyer's thinking that } \\
\text { correspond to these particularities }\end{array}$ & Tools for studying the qualities \\
\hline Orientation to the result in professional activity & Practical orientation of thinking & $\begin{array}{l}\text { Questionnaire for diagnosing the practical orientation of } \\
\text { thinking (N.V. Volodina, L.P. Urvantsev) }\end{array}$ \\
\hline $\begin{array}{l}\text { High legal regulation of the professional } \\
\text { behavior }\end{array}$ & $\begin{array}{l}\text { High standardization of behavior, low } \\
\text { inclination to deviant behavior }\end{array}$ & $\begin{array}{l}\text { Scale G 16- of R. Catell's 16-factor personality } \\
\text { questionnaire }\end{array}$ \\
\hline $\begin{array}{l}\text { Extreme character of law enforcement activity } \\
\text { of many lawyers }\end{array}$ & Emotional stability & $\begin{array}{l}\text { Scale C 16- of R. Catell's 16-factor personality } \\
\text { questionnaire } \\
\text { RNT Psychological characteristics of temperament (scale } \\
\text { "Emotional excitement") }\end{array}$ \\
\hline $\begin{array}{l}\text { Non-standard, creative character of a lawyer's } \\
\text { work }\end{array}$ & High creativity & $\begin{array}{l}\text { Questionnaire of abilities of a creative personality (O.A. } \\
\text { Shlyapnikova, M.M. Kashapov) }\end{array}$ \\
\hline
\end{tabular}




\begin{tabular}{|l|l|l|}
\hline $\begin{array}{l}\text { Extreme diversity of tasks solved by a } \\
\text { professional lawyer }\end{array}$ & High mental flexibility & $\begin{array}{l}\text { RNT Psychological characteristics of temperament (scale } \\
\text { "Rigidity") }\end{array}$ \\
\hline $\begin{array}{l}\text { The necessity of reconstructing the events, } \\
\text { determining legally important circumstances } \\
\text { and qualifying them from the standpoint of law }\end{array}$ & High intellect & Scale B of R. Catell's 16-factor personality questionnaire \\
\hline
\end{tabular}

Thus, the above approach and the package of techniques suggested allows studying the particularities of a lawyer's professional thinking in close connection to the requirements of the profession.

\section{Results and Discussion}

We performed the study with students of full-time department of the faculty of law of P.G. Demidov Yaroslavl State University. The total of 282 people took part in the research. As the control group, the students of the faculty of economics of P.G. Demidov YarSU were engaged (143 people). The students of this faculty were selected because the professions of a lawyer and an economist have an essential similarity: both belong to "human - human" type professions, both deal with managerial activity as well as with paperwork. This similarity allows singling out the particularities of thinking which are inherent exactly in law students easier.

The results of research conducted have shown that there are no significant distinctions between the students of year 1 and year 2 of the faculty of law (see Table 2). The same situation is characteristic for the control group (economics students). We believe this is to a large extent due to the subjects taught to law and economics students being considerably similar in the first years.

Table 2. Comparison of average values for students of various years of the faculty of law (the significant distinctions are given in bold type)

\begin{tabular}{|l|c|c|c|c|c|}
\hline & Year 1 & Year 2 & Year 3 & Year 4 & Year 5 \\
\hline Intellect & 4,145 & 4,485 & 4,065 & $\mathbf{4 , 5 5 9}$ & 4,889 \\
\hline Emotional stability & 7,371 & 7,32 & 6,774 & 6,814 & 6,778 \\
\hline Standardization & 7,629 & 7,583 & 7,774 & 7,237 & 7,815 \\
\hline Rigidity & 11,24 & 11,17 & $\mathbf{1 3 , 8 4}$ & $\mathbf{1 1 , 6 3}$ & 11,41 \\
\hline Emotional excitement & 9,823 & 9 & 10,52 & 10,03 & 10,33 \\
\hline Practical orientation of thinking & 17,4 & 17,84 & $\mathbf{1 5 , 7 1}$ & 17 & 17,3 \\
\hline The level of development of creative personal capacities & 35,13 & 34,56 & $\mathbf{3 0 , 5 8}$ & 32,12 & 33,48 \\
\hline
\end{tabular}

At the same time, the students of years 2 and 3 differ in a number of properties. In particular, significant distinctions according to Mann-Whitney criterion were demonstrated in three criteria: flexibility and rigidity, practical orientation of thinking, and the level of development of creative personal capacities.

So, in third-year students, rigidity is clearly developed more than in second-year students. The average value in "Rigidity" scale is 11,17 points in second-year students, which means the average manifestation of rigidity, although with a marked trend toward a high extent (the average extent is 7 to 11 points included). In third-year students, the average value in this scale is 13,84 , which shows a high extent of rigidity (12 to 15 points included).

The reduction of practical orientation of thinking is also clear. So, in second-year students, an average score in practical thinking orientation scale amounts to 17,84 , which means an average extent of the practical orientation of thinking that, however, tends to the low extent (the average manifestation of practical thinking orientation is 14 to 28 points in the questionnaire by N.V. Volodina and L.P. Urvantsev). In third-year students, even smaller extent of practical thinking orientation has been found which nevertheless fits within the average extent positions (the average value of thirdyear students is 15,71 in this scale).

As for the level of creative personal capacities, it is also reduced in third-year students as compared to students of year 2. In particular, the second-year students demonstrate on average a very high level of development of creative personal capacities (the mean value is 34,56 points, with the score of over 34 points standing for a very high development level of the capacities according to the scale of creative personal capacities development). The third-year students show a high development level of creative personal capacities (the average value being 30,58 points, with results from 38 to 34 being referred to a high development level of creative personal capacities).

As well, at the trend level, the lower level of intellect in third-year students as compared to the second-year ones has to be pointed out (the results do not have a significant distinction according to Mann-Whitney criterion, though). In 
particular, the average value in second-year students is 4,485 stens according to the intellect scale of Catell's questionnaire while it is only 4,065 stens in third-year students.

Within the control group (economics students), there have been no significant distinctions found between students of years 2 and 3 .

When comparing the students of years 3 and 4 , there are clear significant distinctions according to two parameters: intellect and rigidity.

So, the fourth-year students feature a clear increase of the intellect as compared to third-year ones. The average value of intellect increased from 4,065 to 4,559 stens. Thus, there is clear "pocket" in this scale in year 3 which nevertheless is compensated over and above in year 4 (the average value in the intellect scale is higher in fourth-year students than in second-year ones).

There is also a clear reduction of rigidity of thinking - from 13,84 in third-year students to 11,63 in fourth-year ones. Thus, the fourth-year students show a marked return to the average extent of rigidity, although apparently bordering on the high extent. It should also be pointed out that on balance the rigidity in fourth-year students though having gone down turned to be at a higher level than that in second-year students (11,63 in fourth-year students versus 11,17 in secondyear ones).

We can also speak about a slight increase of the average level of practical thinking orientation (from 15,71 points in students of year 3 to 17 points in those of year 4) as a trend, as well as higher level of creative personal capacities from 30,58 points in third-year students to 32,12 in fourth-year ones.

Within the control group, we have not discovered any significant distinctions between students of years 3 and 4 .

When comparing students of years 4 and 5 , no significant distinctions have been found, yet there is a clear trend of increase of intellect - from 4,559 stens in fourth-year students to 4,889 stens in fifth-year ones.

No significant distinctions have been found in the control group, either, although we can speak about higher standardization in economics students of year 5 (the average value in "behavior standardization" scale is 8,667) as compared to those of year 4 (the average value in standardization scale is 7,111 ) as a trend.

If we compare years 1 and 5 of the faculty of law, then it is only the distinction in the intellect that will be a significant distinction. In particular, the average value of year 1 is 4,145 , while it makes 4,889 in year 5 .

As for the control group, here it is only the distinction in standardization index that will be significant when comparing the economics students of years 1 and 5. In particular, the first-year students have the average value of standardization scale equal to 6,816, while this value is significantly higher in fifth-year students and amounts to 8,667. At the trend level, we can also point out the increase of creative personal capacities (from 33,05 in first-year students to 35,93 in fifth-year students). No significant distinctions in the intellect of students of years 1 and 5 of the faculty of economics have been found.

\section{Conclusion}

On balance, it can be stated that it is for year 3 that a significant reduction of most professionally important indices is characteristic. In years 4 and 5, the indices are restored either in part or to a higher extent as compared to year 2. This result allows us to say that year 3 is a crisis stage in the professional development of law students.

The results of the control group indices dynamics are also very interesting. As we can see, in economics students the above indices remain unchanged on the whole and it is only at the last years that the increase in standardization of behavior takes place. We think such stability of indices is due to other characteristics of thinking being developed in economics students during their study at the higher education institution which were not measured by us within this research.

We believe a surge of rigidity in third-year students, like the reduction of creative personal capacities, is equally due to entering the profession and specific character of formation of the professional thinking. The reduction of practical orientation of thinking is conditioned by final inclusion into the learning activity which is known to have a brightly manifested theoretical character.

It has to be pointed out that the above three parameters are manifested slightly worse in year 5 than in year 1 (e.g. the level of creative personal capacities is almost two points lower in fifth-year students as compared to the first-year ones). We think this reduction is due to the crisis of year 3 not being overcome completely and that the said parameters are eventually restored as late as within the professional activity.

As for the intellect, it is restored earlier than the other parameters (yet within the learning activity) and exceeds the average data for year 3 . We consider this to be due to the fact that within the learning activity students have to master individual areas of law at a qualitatively more difficult level when passing to more difficult subjects, which is the cause of 
intellect enhancement.

Thus, the development of qualities of thinking in lawyers at the higher education institution stage of professionalization is distinguished by heterochrony. In particular, there is a clear crisis in development of professional thinking in law students in their year 3 . Moreover, the consequences of this crisis prove to be not overcome completely by year 5 (the indices which were reduced in year 3 are never restored in full). We believe that finally the consequences of crisis revealed are eliminated as late as during professional activity.

\section{Acknowledgments}

The work has been performed with the financial support of project No. 25.2356.2014K within the project part of the R\&D state assignment to the university.

\section{References}

Baron, J. (1985). Rationality and intelligence. New York: Cambridge University Press.

Kornilov, Yu.K. (2000). Psikhologhiya prakticheskogo myshleniya [Psychology of practical thinking]. Yaroslavl: YarSU.

Karpov, Yu.K. Kornilov. Prakticheskoe myshlenie: teoreticheskie problemy i prikladnye aspekty [Practical thinking: theoretical problems and applied aspects]. Monograph. Yaroslavl: YarSU? 80-104.

Kashapov, M.M. (2007). Ob akmeologhicheskikh predposylkakh sozdaniya strukturno-funktsionalnoi teorii tvorcheskogo myshleniya professionala [On acmeological prerequisites for creating a structural and functional theory of creative thinking of a professional]. In: A.V.

Perkins, D. N. (1989). Reasoning as it is and could be. In: D. Topping, D. Crowell, \& V. Kobayashi (Eds.) Thinking: The third international conference. New Jersey: Lawrence Erlbaum, 175-194.

Romanov, V.V. (2004). Yuridicheskaya psikhologhiya [Legal psychology]. M.: Yurait.

Rubinshtein, S.L. (2006). Osnovy obshchei psikhologhii [Foundations of general psychology]. SPb.: Piter.

Smith M.L. (2008). The Transition to University: Adaptation and Adjustment. Master of Arts Dissertation. Saskatoon: University of Saskatchevan.

Sternberg, R. J., Wagner R. K. (1986). Practical intelligence. Cambridge: Cambridge University Press.

Taylor, P.G. (2004). Exploring student adaptation to new learning environments: some unexpected outcomes. International Journal of Learning Technology, 1, 100-110.

Teplov, B.M. (1990). Um polkovodtsa [A commander's mind]. M.: Pedagoghika.

Vasiliev, V.L. (2009). Yuridicheskaya psikhologhiya [Legal psychology]. Saint-Petersburg: Piter.

Warren, J.S. (2009). Social support provisions as differential predictors of adaptive outcomes in young adolescents. Journal of Community Psychology, 37 (1), 106-121. 